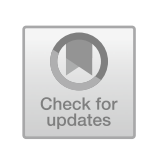

\title{
The Public and Public Health
}

\begin{abstract}
In this chapter, we explore conceptualisations of the public, of public health and the relationship between these. We suggest there are three key ways in which 'the public' is seen: as a collection of people; as a space for action; and as a set of values. Likewise, public health can be understood in terms of: the challenges it faced or faces; the systems employed to deal with these; and as a kind of philosophy or outlook. We also look at the changing nature of the relationship between the public and public health. We begin in the nineteenth century, move on to the early twentieth century, and map out the broad elements of the dynamic surrounding public health and the public after 1945 .
\end{abstract}

Keywords The public - Public health · Public health history · Population · Citizenship · Public sphere

Who or what is the 'public' in 'public health'? How have these concepts changed over time, and what impact does this have on the relationship between the public and public health? In this chapter we set out to address these critical questions. We argue that the 'public' and 'public health' are not fixed or concrete entities: these are constructions that alter over time and place. The slipperiness of such concepts makes them hard to define, but by studying their malleability, important aspects of the nature of the

(C) The Author(s) 2019

A. Mold et al., Placing the Public in Public Health in Post-War Britain, 1948-2012, Medicine and Biomedical Sciences in Modern History, https://doi.org/10.1007/978-3-030-18685-2_2 
social and political action that surrounds collective and individual health are revealed. For instance, it is often the case that there is not one 'public' but many 'publics'. A single, unitary public may have rhetorical value, but the practice of public health tends to encompass a range of publics. Likewise, although 'public health' in its literal sense as the 'health of the public' might appear to be a stable object, it is a moving target shaped by a range of forces, systems and ideas.

In this chapter, we seek to untangle some of these complexities through an exploration of theoretical and historical perspectives on the public, public health and the relationship between these. We begin by examining the concept of 'the public'. The public, like 'the nation' or 'the masses' is a construct, and there are, we suggest, three key ways in which 'the public' is seen. Firstly, as a collection of people; secondly, as a space for action; and finally, as a set of values. After exploring each of these in turn, we analyse the notion of 'public health'. Different definitions of public health will be examined, and by reflecting on how these have changed over time, we identify three core components. Public health can be seen in terms of: firstly, the challenges it faced or faces; secondly, the systems employed to deal with these; and finally, as a philosophy or outlook. In the final section of the chapter, we look at how the relationship between the public and public health in Britain has changed over time. We begin in the nineteenth century, move on to the early twentieth century, and map out some of the broad elements of the dynamic surrounding public health and the public in the post-Second World War era. Developments from the late 1940s onwards will be interrogated in more detail throughout the rest of the book, but it is important to both set the scene and think about how continuities and changes in publics and public health play out over the longue durée. This reiterates our argument that both the public and public health are multiple and ever-changing, but it also helps to point out when, where and why such changes may have occurred.

\section{The Public}

'The public', like other grand organising concepts such as 'the nation', or 'the masses', is imaginary. As the legal scholar John Coggon points out, the notion of 'the public' has much in common with Benedict Anderson's concept of imagined community. No member of the public can know all the other members of the public, but in their minds or those of others they are part of one community (Coggon 2011). Similarly, drawing on Raymond 
Williams's analysis of the 'masses', the historian David Cantor notes that there was no such thing as 'the public', only ways of seeing it (Cantor 2002). What is meant by the 'public', according to social policy analysts Janet Newman and John Clarke, is often 'elusive' (Newman and Clarke 2009, 11). Some critics have even suggested that 'the public' is too ambiguous a term to be of use (Mathews 1984, 122). Yet, the concept is employed frequently, and in many contexts, so it clearly has value. Analysing the ways in which the concept of 'the public' is mobilised helps provide useful insight into its meanings. As Coggon and Newman and Clarke indicate, 'the public' exists simultaneously as an object and as a descriptive, normative category. We can see how this works in practice by considering the ways in which 'the public' operates within definitions of public health. Marcel Verweij and Angus Dawson identify two 'senses' of the public within public health. The first relates to the state of the health of the public, the population or the collective. The second revolves around a set of interventions aiming to protect the health of the public. The public is thus a thing to be targeted and a process of collective action (Verweij and Dawson 2007). This is useful but leaves out a sense of the values attached to the concept of 'the public'. As Newman and Clarke argue, part of what makes the public is a set of legal and democratic values that mark out a domain distinct from private interests (Newman and Clarke 2009, 4).

From these different descriptions of 'the public' we derive three sets of meanings of the public that deserve further analysis. Firstly, the public as the people, citizens and/or the population; secondly, the public as a space for action, intervention and service provision; and finally, as a set of collective values, often, but not always, opposed to private interests. These groups of meanings reflect the different senses of the public discussed in the literature but also take us beyond it, towards thinking about how 'the public' is deployed in specific contexts and how this changes over time.

\subsection{Public $=$ Population, Citizens}

'The public' is often seen as synonymous with the 'population' or the 'citizens' of a place. Populations and citizens are not the same entity, but they are related concepts as they both refer to the public as a noun. The notion of the 'population' is particularly relevant here, as it is bound up with the history and practice of public health. The collection and collation of statistics about life and death that began in Britain as early as the seventeenth century was crucial to the development of knowledge about 
the public and its health (Porter 1999, 5, 49-52). The Annual Reports of the Registrars-General running from 1839 to 1973, and today's equivalent Office for National Statistics publications, were an essential resource for headline data on mortality, and, by extension, endemic and newly emergent diseases. These ways of viewing the public, based on assumptions of distribution of data and probability, are essential to both public health's epistemological roots and its scientific credibility.

Yet, the population was more than a statistical product. As Tom Crook and Glen O'Hara point out, the generation of numbers about the public enabled them to be imagined in new ways (Crook and O'Hara 2011). The social epidemiologist Nancy Krieger argues that in addition to the common understanding of population as a statistical entity defined by innate attributes, populations are also dynamic, defined by relationships among their members and with other populations (Krieger 2012). Like 'the public', 'population' is relational (Cantor 2002). This can be seen when the uses to which this concept is put are examined in more detail. For followers of Foucault, population was a product of bio-political power: coming to know the population was essential to governing it (Foucault 2007). What the sociologist David Armstrong termed 'surveillance medicine' brought everyone-sick and well-into the purview of public health authorities (Armstrong 1995). The generation of data about the population and its health was essential to its improvement, but also to the expansion and development of public health as a practice and a philosophy. Attempts to improve population health and develop the systems to do so were a crucial part of the formation of the modern state (Szreter 2003; Porter 1999; Crook 2016; Hamlin 2010).

Population, however, was not the only way in which states envisaged the people in relation to health or other spheres. Notions of citizenship were fundamental to states and their government from Ancient Greece onwards (Heater 2004, 2006). Yet, the concept of what it meant to be a citizen changed considerably over time, especially surrounding the rights and responsibilities of states and citizens. As Dorothy Porter notes, public health in the nineteenth century was concerned with protecting citizens from epidemic diseases (Porter 1999, 63-96, 111-46). By the early twentieth century, ideas about social citizenship came to the fore. These emphasised the provision of public services, like healthcare, as part of the social contract between state and citizen (Marshall 1992). The post-war establishment of the welfare state in Britain, and particularly the NHS, is often seen as the apogee of social citizenship. For Porter, this was dictated 
by a social, rather than economic logic, one that justified intervention from the state to achieve national efficiency and improved public health. Closely related to the concept of social medicine, social citizenship emphasised a medicine of society for society (Porter 2011, 113-24). Social citizenship, according to Harry Oosterhuis and Frank Huisman, meant that healthcare was a right not a favour (Oosterhuis and Huisman 2014).

From the 1970s onwards, however, social citizenship and the entitlements it encompassed came under threat. The rising costs of healthcare, coupled with the growth of neoliberalism, and the apparent increase in incidences of lifestyle-related disease, provoked a new formulation of health citizenship. What Oosterhuis and Huisman term 'neo-republican citizenship' emphasised civic responsibilities and obligations in relation to health. They argue that neoliberal ideas about the value of market models of healthcare provision and the importance of individual choice and autonomy combined with a 'new public health' that placed the responsibility for managing public health risks squarely on the citizen rather than society (Oosterhuis and Huisman 2014). Yet, as Porter remarks, there was still a role for the state in the provision of healthcare and intervening in the social and political environment to allow citizens to achieve better health (Porter 2011, 113-24). We examine the changing nature of health citizenship in greater detail throughout the book, but it is worth noting that whatever notion of citizenship held sway, this was not all-encompassing. As Matthew Grant comments in his survey of formulations of citizenship in post-war Britain, certain groups of individuals were often excluded from the notion of British citizenship and, at the same time, citizens themselves could engage with ideas of citizenship to make it their own (Grant 2016). When viewed as either populations or citizens, the public was not merely a passive actor.

\subsection{Public $=$ Space for Action}

The capacity for the public to act compels us to think about the spaces in which it acts, or is acted upon, and what these actions involve. 'The public' can be regarded not just as an object, but also as a space for action. One of the principle ways of viewing this surrounds the notion of the public sphere. The chief architect of this concept is the German theorist Jurgen Habermas. Beginning in the late seventeenth century, Habermas charts the development of new forms of bourgeois sociability related to the rise of capitalism (Habermas 1989). In places such as coffee houses and salons, and through other mechanisms like the popular press, a separate space distinct from 
the state and the private realm began to emerge (Calhoun 1992; Sturdy 2002). This space, which Habermas characterised as the 'public sphere', allowed individuals to debate collectively issues of wider significance. Yet, almost as soon as it began to emerge, the public sphere came under threat. As the public enlarged beyond the bourgeoisie, particularly through the extension of the franchise to the working classes, and capital and economic power became concentrated in the hands of the wealthy, the public sphere became riven by competing interests. The state had to intervene to mediate such conflicts, resulting in the public sphere and the state becoming ever more interlinked. The distinction between state and society, and between the public sphere and the private sphere, broke down. As a result, instead of being concerned with rational debate, the public sphere became the site of negotiation between interest groups. Once the bourgeois public became a mass public, participation in the public sphere was reduced to a plebiscite with the power to direct state action and limited to simple voter approval or disapproval.

Developing Habermas's theory, Craig Calhoun contends that the enfranchisement of the working classes in the nineteenth century and women in the early twentieth century, followed by the rise of identity politics in the latter half of the twentieth century, fractured the unified public sphere, leading to the creation of multiple or overlapping public spheres (Calhoun 1992). The notion of a single public no longer held weight, according to Nancy Fraser, as even subordinated groups were able to come together to form 'subaltern counter publics' (Fraser 1990). The literary scholar Michael Warner contends that there was nothing 'subaltern' about some of these counter publics: they set themselves up in direct opposition to 'the public' and offered alternative ways of thinking about the nature of public life (Warner 2002a, b). Once again, the literature suggests that not only are there multiple publics but that these exist in relation to one another and sometimes in opposition to dominant formulations of 'the public'.

Habermas's theory of the public sphere, influential though it is, is not the only way of thinking about how the public is enacted. The other key space for action surrounds what is done for, or in the name of, the public. This encompasses many areas, but the most relevant here is the provision of public services. As Newman and Clarke note, public services are 'both constituted by, and constitutive of, notions of publicness' (Newman and Clarke 2009, 4). Public services help shape publics (and vice-versa) in multiple ways. For instance, public service bodies act as channels for public 
culture. In their study of the BBC in Britain during the 1980s, Patricia Holland, Hugh Chignell and Sherryl Wilson explore the nature of public service broadcasting and how it dealt with the public (Holland 2013). They suggest that during this period, notions of public service shifted away from a paternalistic understanding of the public as clients and towards a more libertarian view of the public as consumers. Underpinning this was a change in the ideals attached to publicness. The public then, is not just about actors and action, it is also about values.

\subsection{Public $=$ Values}

The values ascribed to publicness are often described in relation to what the public is not. The most common juxtaposition is public versus private. A set of binaries revolve around different conceptions of public and private. Public is often taken to mean collective, whereas private refers to the individual. Or it can be a set of spaces: private relates to the home, public to the spaces outside it. Within public health practice, there have long been tensions over the distinction between the public and the private realms. In the nineteenth century, the development of legislation around sanitation and the cleansing of environments encroached upon private spaces as well as public ones (Daunton 1990). Other kinds of public health initiatives, such as vaccination, were seen by some to impinge upon the private body of the individual and their right to determine what happened to it (Durbach 2005). A further reconceptualisation of the boundary between private and public was implicated in the rise of lifestyle-related disease, as what might previously have been thought of as private matters, like drinking and smoking, came to be seen as public health dangers.

In the context of healthcare and other welfare services, 'private' can also mean market-orientated or for profit, while 'public' describes state-funded or supplied forms of healthcare. Values are often attached to these binaries. For some, public services, like the NHS, are an inherent good which needs defending against the incursion of private interests (Pollock 2005). Others argue that public service providers may not always act in the best interests of individuals and that private, market-orientated modes of working would be more efficient and effective (Le Grand 2003, 2007). In this book, we do not attempt to arbitrate between such opposing views, rather we point out where these tensions exist and explain how they came into being.

One long-running trend associated with the values connected to publicness is a fear that the public is in decline. The American sociologist Richard 
Sennett outlined 'the fall of public man' from 'his' [sic] height in the eighteenth century to a 'state of decay' by the time of writing in the mid-1970s. For Sennett, it was the bleeding together of private and public realms, especially around feelings and sentiments that were previously confined to the private sphere, that brought about decline (Sennett 1977). Approaching this from a rather different perspective, Nikolas Rose argues for the role of psychology and other 'psy' disciplines in creating private selves, but for Rose there are other influences too, such as biomedicine and biotechnology which help 'make up' (borrowing from Ian Hacking) 'biological citizens' (Rose 1999, 2006, 2010; Hacking 2006). For other commentators, the growing importance being ascribed to individuals was the flip-side of the demise of collective ways of thinking about people and their interests. David Marquand outlines what he sees as the 'hollowing out' of the public domain in Britain since the 1970s. Marquand contends that the cultural revolution of the late 1960s and 1970s helped to break down distinctions between the public and the private as the personal became political. At the same time, economic crisis opened the door to neoliberal attacks on collective welfare systems. The deregulation and privatisation of public services that took place from the 1980s onwards, Marquand asserts, 'narrowed the public domain and blurred the distinction between it and the market domain' (Marquand 2004, 2).

Despite such elegies for the public, the extent to which the public can be said to have declined depends on the values which are ascribed to it. As Newman and Clarke point out, there are all sorts of ways in which 'publicness' is retained and even remade within contemporary public services (Newman and Clarke 2009). Efforts to increase public participation in public services, for instance, have proliferated in recent decades (Stewart 2016; Hogg 2009; Baggott et al. 2005). 'The public' is still a concept that does work, even if the nature of this work may have changed over time. This can be seen when we broaden the discussion away from 'the public' and think about 'public health'.

\section{Public Health}

Describing the nature of 'public health' is just as problematic as outlining that of 'the public'. Historian Christopher Hamlin points out that 'The great debate in the history of public health is what public health is and what it should be' (Hamlin 2011, 411). The very process of defining public health is a normative exercise, and one which has changed over time. 
Nonetheless, in their survey of a series of definitions of public health from the 1920s onwards, Verweij and Dawson identify two common elements. Firstly, public health is about the state of the health of the public, that is the population, the whole or the collective. Secondly, public health encompasses interventions or practices that are aimed at protecting the health of the public. These interventions are not primarily those of an individual, but involve some form of collective action (Verweij and Dawson 2007). A much-used definition of public health is that put forward by the American bacteriologist CEA Winslow in 1920. He stated that public health is:

the science and the art of preventing disease, prolonging life, and promoting physical health and efficiency through organized community efforts for the sanitation of the environment, the control of community infections, the education of the individual in principles of personal hygiene, the organization of medical and nursing service for the early diagnosis and preventive treatment of disease, and the development of the social machinery which will ensure to every individual in the community a standard of living adequate for the maintenance of health. (Winslow 1920)

Many contemporary definitions of public health draw on Winslow's, but the elements that get removed and added are often telling. The historian Virginia Berridge cites two definitions of public health in UK government reports, one from 1988 and one from 2004. Both reports use the formulation of public health as the 'science and art of preventing disease, prolonging life and promoting health through the organised efforts of society', but the 2004 definition adds 'and informed choices of society, organisations, public and private, communities and individuals'. Berridge ascribes the difference in definitions to the widening range of actors involved in ensuring that population health be improved and the changing politics of what 'public health' is thought to encompass (Berridge 2016, 3-4).

The politics of defining public health is also explored by Coggon. He identifies 'seven faces of public health'. First, he suggests, public health is a political tool. Public health is used as a compelling reason for formulating a policy. Second, public health is a business of government. Public health is a government function, whether that relates to specific agencies or governmental powers that affect health. Third, public health operates as a social infrastructure; it can be used to describe a society's organisation with respect to health issues. Fourth, public health is a professional enterprise. Fifth, public health can be used as a qualifier to represent prob- 
able benefits or harms within a population. Sixth, public health is a moral enterprise: any member of the public may do harm or benefit to the others through their actions. Finally, public health is the population's health; it is the health of the population either in aggregate or by distribution (Coggon 2011). These seven faces are useful, but for our purposes a little unwieldy. Instead, we group ways of defining 'public health' around three core sets of meanings. Firstly, public health has often been understood in relation to the challenges that face population health. Secondly, public health can be described as a set of systems. Finally, public health can be thought of as a philosophy or outlook.

\subsection{Challenges}

Public health is often shaped by the issues it contends with. Just as the issues have changed over time, so too has the meaning of public health. As Porter remarks, for many, the history of public health 'conjures up an image of investigating toilets, drains and political statutes through the ages' (Porter 1999, 1). Although public health in the sense of what Porter calls 'collective action in relation to the health of populations' has existed for centuries, a particular type of 'public health' that developed during the nineteenth century, and was connected to sanitation and the state, tends to dominate conceptions of 'public health' in the past (Porter 1999, 4). Such conceptions can pose problems when thinking about more recent formulations of public health. Jane Lewis asserts that "While the focus of nineteenth-century public health seems clear, writers have found it hard to describe the content of public health in the twentieth century' (Lewis 1986, 5). Lewis suggests that after the Second World War public health 'allowed itself to be defined by the activities is undertook. The idea of public health thus remained indistinct' (Lewis 1986, 3). We get to grips with this argument in more detail later in the book, but for now it is worth surveying briefly the different types of challenges that were defined as public health problems, and how these shaped conceptions of 'public health' at various times.

The nineteenth century was a period when concerns about the impact of sanitation and the environment on health dominated. This was the case in Britain, Europe and North America (Baldwin 2005; Nathanson 2007; Hamlin 2010; Rosen 1993). Endemic and epidemic infectious diseases such as cholera, typhoid, typhus and smallpox were the leading causes of morbidity and mortality. Political, social and economic pressures to com- 
bat these diseases resulted in the development of bureaucratic systems and technological fixes to fight infection. The building of sewers, the development of refuse collection, the provision of clean water, sanitary inspection, the introduction of vaccination, and so on, were all measures designed to protect and improve population health. By the early twentieth century, many infectious diseases appeared to have been conquered, as morbidity and mortality from these conditions decreased. The exact role played by public health initiatives in this is disputed (improvements in nutrition and the quality of housing were also important) but it is the case that by the early 1900s public health authorities began to shift their attention to other issues (McKeown 1979; Szreter 2002). Infant mortality and child health, tuberculosis and personal and social hygiene became key concerns (Welshman 2001; Niemi 2016).

As the incidence of infectious disease continued to decline throughout the twentieth century, the nature of what was meant by 'public health' also shifted. The diseases people suffered, and therefore the activities necessary to improve population health, changed. By the post-Second World War period, it appeared that an 'epidemiologic transition' had taken place (Omran 2005; Weisz and Olszynko-Gryn 2010; Armstrong 2014). Chronic conditions, such as heart disease and cancer, had overtaken infectious disease as the leading cause of death (Weisz 2014). From the mid1950s, epidemiological studies began to demonstrate a link between individual behaviour and certain chronic conditions. The most famous of these concerned smoking and lung cancer, but other work also found connections between coronary heart disease and diet as well as levels of exercise (Doll and Hill 1950; Morris 1957). Such conditions and their aetiology seemed to pose a new type of challenge to the public's health and those that sought to safeguard it. Improving public health now involved persuading individuals to change their behaviour and thus decrease their chances of developing a chronic disease. What became known as 'lifestyle public health' focused on identifying and reducing 'risk factors' for chronic disease through health education and other preventive measures such as screening (Rothstein 2003; Oppenheimer 2006). By the end of the twenty-first century, the challenges facing public health were vastly different from those of 200 years prior, and so 'public health' as an enterprise was also altered. 


\section{$2.2 \quad$ Systems}

To address collective health problems, a range of different systems were created at different times. Tom Crook, in his book on late nineteenth- and early twentieth-century public health describes public health 'systems' as: 'a shifting assemblage of interacting parts and practices, people and things' (Crook 2016, 3). These systems were complex and dynamic, and not necessarily 'systematic' in the sense of being methodical, but nonetheless their architects hoped that they would be. Within this broad definition of a public health system, Crook identifies a wide range of actors and authorities. These include central and local government and their agents, as well as other entities such as private companies and civil society. Although Crook is describing a period over 100 years ago, many of the same key actors can be identified throughout the recent history of public health systems. That is not to say that public health systems stay the same. Indeed, the nature of public health systems, and especially the location of public health services, altered over time. A key area of both continuity and change surrounds the relative role of central versus local government.

Since the introduction of key pieces of legislation such as the Public Health Act in 1848, the national government may have directed developments, but it was often local government that had to take action. The establishment of local Boards of Health, and the creation of the role of the Medical Officer of Health $(\mathrm{MOH})$, put the onus on local government to develop public health services and systems. The duties of the $\mathrm{MOH}$ changed over time in line with the challenges facing population health. In the late nineteenth and early twentieth centuries these included sanitary inspection, vaccination, the collection of statistics on death and disease and directing improvements to housing. By the early twentieth century, according to Martin Gorsky, the $\mathrm{MOH}$ had reached the height of his $(\mathrm{MOH}$ were almost all men in this period) powers (Gorsky 2007). MOH had responsibility for (among other things) state welfare programmes to improve the health of children and mothers, school medical services, screening and, after 1929, the former Poor Law workhouses which operated as chronic disease hospitals. Some historians have suggested that during the inter- and post-war years $\mathrm{MOH}$ were ineffective and failed to adapt to the changing nature of public health problems (Webster 1988; Lewis 1986, 1991). Others have argued against this, pointing to individual $\mathrm{MOH}$ who were willing and able to deal with new and ongoing public health problems such as malnutrition (Gorsky 2008; Welshman 1997b). 
Regardless of the effectiveness or otherwise of $\mathrm{MOH}$, a key moment in the development of public health systems in Britain occurred at the time of the creation of the NHS in 1948. Some of the duties and responsibilities of $\mathrm{MOH}$ and local government, including the chronic disease hospitals, were transferred to the new health service. $\mathrm{MOH}$ had fewer services to administer, but they still had a role to play in areas such as disease prevention and health education (Diack and Smith 2002; Welshman 1997b; Mold 2018). Yet, some of these responsibilities were also shared with other agencies, including central bodies like the Ministry of Health and the Central Council for Health Education, and other local actors such as General Practitioners (Blythe 1987). Further change came after the NHS reorganisation in 1973-1974. Responsibility for public health was removed from local government and brought within the NHS. The post of the $\mathrm{MOH}$ was scrapped and replaced with that of the community physician. Integrating 'public health' services and functions within the NHS was supposed to make them more effective, but there were difficulties. The community physician worked within the local NHS structures to coordinate preventive services. Many community physicians struggled with their new role, attempting to balance health service management with planning and specialist preventive duties. It was also unclear what 'community medicine' meant, and what this empowered the community physician to do (Lewis 1986).

More recently, the location of public health services and functions in England (the situation is different in each of the devolved nations) changed again. Public health once more became the responsibility of local government following the Health and Social Care Act, 2012. Commissioning for public health services was moved out of the NHS and devolved to local government. Directors of Public Health were relocated to local authorities, where they oversee health protection and improvement in their area, as well as the provision of public health services such as smoking cessation, sexual health and drug and alcohol treatment (Gorsky et al. 2014). At the same time, central government and the NHS also retain some responsibility for public health, as well as a whole host of other agencies and actors. Clearly there is not one 'public health system': it is diffused and located in various places, and has been for decades. Yet it can be helpful to think about the myriad ways in which systems shape ideas about public health, and how ideas about public health shape systems. 


\subsection{Outlook}

What distinguishes a 'public health system' from any other health system? In part, this can be attributed to the philosophy or outlook of the system and the people running it. Commentators often talk about a 'public health approach' to an issue, or the need to find a 'public health solution'. This can be seen, for instance, in relation to illegal drug use. In 2016, two leading public health agencies called on the UK government to reorientate drug policy towards improving and protecting public health rather than focusing on criminal justice (Royal Society of Public Health and Faculty of Public Health 2016). The emphasis on health protection and health improvement was no coincidence, as these are two of the three core functions of public health outlined by one of the report's authors, the Faculty of Public Health. Yet, as Berridge notes, the 'core functions' of public health are also influenced by the location of public health services (Berridge 2016, 6). Moreover, the existence of the Faculty of Public Health, as the standard setting body for public health practitioners, complete with qualifications, exams and membership, points towards the development of a public health 'profession'. The Faculty was established in 1972 following a recommendation from the Todd Commission on medical education. Yet the nascent profession was far from united. Lewis highlights considerable tensions between community physicians and academics, such as Jerry Morris, who wanted to ground public health practice more firmly in epidemiology (Lewis 1986, 102). This casts doubt on the idea that there was or ever could be a single 'public health view' of any given issue. Yet, certain elements have, over time, been associated repeatedly with a public health outlook or approach.

A key feature of a public health view is the emphasis on tracking and surveying health and illness at a population level. One of the roles of $\mathrm{MOH}$ and their successors was to gather and record statistics on the health of the people in their area. Epidemiology was central to the development of public health practice and public health research from the nineteenth century onwards. The nature of epidemiological theory changed over time, in line with patterns of disease and wider medical thought. There was, for instance, often tension between biological and social explanations of disease causation and its spread (Krieger 2014). However, one constant surrounds the need to explain the distribution of disease within the population. Obtaining the data to analyse the causation and spread of disease required an element of population surveillance. Some scholars, especially those influenced by Foucault, see this as one of the methods by which public health 
authorities exercise power over the population. Armstrong, for instance, argues that the development of surveillance medicine in the early twentieth century expanded public health's gaze to include the entire population, pathologising the normal as well as the abnormal. Alan Petersen and Deborah Lupton contend that this trend persisted with the development of the 'new public health' of the post-war era. They argue that 'Epidemiology is thus one of the central strategies in the new public health used to construct notions of "health" and, through this construction, to invoke and reproduce moral judgements about the worth of individuals and social groups' (Petersen and Lupton 1996, 60). Public health, they suggest, is not just a set of initiatives designed to improve population health, but also a moral enterprise.

Evidence for the ways in which public health practice and research is bound up with morality is certainly not difficult to find. There is a long tradition within public health of blaming the victim, of pathologising individuals (or groups of individuals) rather than focusing on the social conditions that give rise to incidences of disease. This can be seen in nineteenthcentury attempts to blame epidemics of infectious disease on the poor; in early twentieth-century efforts to focus on bad motherhood as a cause for infant mortality; or in late twentieth-century health education campaigns which stigmatised the individual (Hamlin 2010; Apple 1995; Marks 1996; Lupton 2014). But, public health practice also has a counter-vailing tradition which emphasises social justice (Hamlin 2010). Again, this has been present since at least the nineteenth century, and although it was rarely dominant, the importance of social, economic and political structures in accounting for patterns of disease was not totally ignored. One element underpinning these conflicting views are contrasting notions of the place of the public in public health. How has the public been thought of within public health, and how has this changed over time?

\section{The Changing Relationship Between Public Health and the Public}

As we suggested in the Introduction, surprisingly little attention has been devoted to examining the nature of the relationship between the public and public health. Here we briefly survey the limited historical literature on this issue, focusing on three key periods: the nineteenth century; the early twentieth century; and the post-war period. Throughout these eras there was never a monolithic concept of either the public or public health, or a 
fixed relationship between them. 'The public' was construed in different ways and it interacted with a 'public health' that was constantly changing. Nonetheless, certain continuities can be detected. There has long been a role for the public within public health, even if the nature of this public, and its ability to affect change, was often constrained.

\subsection{The Nineteenth Century}

Ideas about the place of the public in public health in nineteenth-century Britain were strongly influenced by broader conceptions of the individual and their rights and responsibilities. Anne Hardy observes that the freedom of the individual was always more important within the British liberal tradition than in other countries such as Germany, something which can be seen in the 1848 Public Health Act. The provisions contained within this key piece of legislation were voluntary, not compulsory. State regulation relating to the individual body was even more contentious, as in the case of the vaccination laws: compulsory vaccination failed partly due to public opposition. Hardy remarks that 'In terms of public health, the case of vaccination demonstrates that there was not one public but many, even before the concept of "public health" had been formulated' (Hardy 2013, 93). The multifarious nature of the public was also reinforced by the extent to which it was interwoven with the state. James Hanley examined petitions to Parliament in the period 1847-1848 for evidence of public reaction to the development of public health legislation. He found that the petitions garnered a large number of signatories. Most of these were male and middle-class, although Hanley suggests that there was some support from working-class organisations too. This led him to conclude that the public was overwhelmingly in favour of sanitarianism as encapsulated within the 1848 Public Health Act (Hanley 2002).

Deborah Brunton investigated public reaction to public health legislation at the local level. Focusing on Scottish cities, Brunton points out that sanitary reform represented a significant intervention into the lives of private citizens. The agencies of local government grew, she suggests, as a response to this. In this way, local government was part of the public sphere, not distinct from it. Brunton argues that private, public and government interests overlapped to the extent that 'the private world of the citizen and the public realm of governance flowed into one another' (Brunton 2002, 172). Crook offers a different perspective on the relationship between the public, the private realm and the state within nineteenth-century public 
health. Drawing on Foucauldian notions of surveillance, Crook examines the role of the public health inspector and suggests that everyone (the public, local government and the state) was involved in inspecting everyone else, all in the name of the public. He argues that 'Inspectors inspected the public and its representatives; in turn, the public and its representatives inspected inspectors and the administrative field of public health' (Crook $2007,381)$. Crook suggests that not all inspectors were resented as unwelcome agents of red tape; some had the respect of their communities. Inspectors also investigated public complaints, which could be quite numerous (Crook 2016, 142).

The ability to complain, though limited, did offer the public some scope to 'speak back' to public health. More active opposition to public health measures, however, was rare. One of the few initiatives that did provoke resistance was vaccination. Nadja Durbach found that anti-vaccination movements included participation from the more 'respectable' working classes as well as middle-class reformers (Durbach 2000). There were also numerous disputes between local and national authorities, and between public health officials and councillors and rate-payers over specific public health initiatives, such as sewerage and water supply systems (Crook 2016). 'The public' did have agency, but the public being conceived of here was almost exclusively white, male and middle-class.

\section{$3.2 \quad 1900-1945$}

The changing nature of population health, and especially the impact of the epidemiological transition from infectious to chronic disease, helped to alter the way that public health authorities viewed the public. Armstrong suggests that instead of being concerned about the relationship between the public and the environment, public health was now interested in the relationships between people (Armstrong 1983). Diseases such as TB and VD were seen as being socially infectious: passed on by contact between individuals. As Porter points out, the development of social medicine meant that there was also interest in the impact of social structure on health and a desire to focus on the 'whole person' rather than just the 'sick man' (Porter 2011, 104-24). Both these trends meant that public health policy authorities began to recognise that improvements in health would not be achieved through technological fixes or enhanced service provision alone, but also through the actions of the public itself. As a result, in the early twentieth century, and especially in the inter-war period, public health practition- 
ers increased their efforts to educate the public in practices intended to improve their health. This can be seen in the establishment of the Central Council Health Education (CCHE) in 1927, and the efforts of $\mathrm{MOH}$ at the local level to educate the public in matters such as personal hygiene and good motherhood (Blythe 1987; Gorsky 2007; Welshman 1997b). These efforts, according to Welshman, were also aimed at promoting a certain standard of morality and designed to enhance citizenship, as well as health (Welshman 1997a).

Although the public was deemed educable in some matters relating to health, there were other circumstances where public health practitioners thought the public could not, or should not, be reached. Elizabeth Toon notes that most of the British medical community in the inter-war period were opposed to cancer education. They believed that the public was so afraid of cancer that it made people irrational. Education was deemed counter-productive, as it would only foster 'cancerphobia' (Toon 2007). The emotional nature of the public was thought to be damaging in other areas too. Cantor, in his study of the Empire Rheumatism Council, found that the medical men that made up the organisation during the 1930s saw members of the public as emotional, ignorant and unable to manage their own urges. It was only by monitoring and directing the emotional currents within the public that the public could be motivated to act in its own best interest. Cantor argues that up until the Second World War, the public was seen as an undifferentiated mass, but after this period the public began to fragment. He contends that the establishment of the NHS, the development of consumerism, and the application of epidemiological categories and scientific techniques began to break up the 'general public' into different groups (Cantor 2002). The extent to which this represented a true fragmentation of ideas about 'the public' is questionable, but this was a time when the public came to matter to public health in new ways.

\subsection{Post 1945}

Public health did not exist in a vacuum. Broad social, political, and economic change had an impact on public health practice and how it regarded the public. Over the course of the second half of the twentieth century, new ways of thinking about groups and individuals came to the fore. Social and political action surrounding gender, ethnicity, and sexuality gave rise to the creation of new identities. These new categories existed alongside and interacted with both each other and older notions of social class (Rosen 
2003; Harris 2003). Indeed, class did not go away as a framing device or as an identity, although it did change as patterns of work, housing and family life also shifted (Savage 2008, 2015). For some critics, the growth of identity categories played a part in the demise of collective ways of seeing people (Marquand 2004). At the same time, the needs, wants and desires of individuals were increasingly prioritised by politicians. The General Election of 1979, and the establishment of the Conservative government under Margaret Thatcher, is often seen as a pivotal moment. The pursuit of a series of policies by Thatcher and her successors, from the right to buy council houses to the creation of an internal market within the NHS, emphasised the ability of individuals to improve their own circumstances. Shaped by neoliberal ideas of the primacy of the market, citizens were increasingly thought of as 'consumers' (Bevir and Trentmann 2007).

The history of consumerism encompasses both individual desires and collective needs (Hilton 2003). Indeed, it was initially hoped that consumerism could empower groups and individuals who had often been ignored. From the 1970s onwards, there were calls for greater public involvement in public services. Consumer bodies were set up within the nationalised industries, and national consumer groups, like the Consumer Council attempted to speak for consumers across the public and private sectors. In health, Community Health Councils (CHCs) were created in 1974 to be the 'voice of the consumer' within the NHS (Mold 2015; Hogg 2009). Although the record of organisations like the CHCs in affecting change was patchy, the citizen-consumer voice could not be ignored. CHCs were scrapped in 2003 and were replaced with an 'alphabet soup' of organisations with varying acronyms and short life spans (Mold 2015, 159-61). Nonetheless, the principle of public involvement within the NHS and other public services is now well-established, even if it is of questionable impact.

Alongside such wider shifts, changes in patterns of disease within the population also served to alter perceptions of the public. From the 1950s onwards, the linking of chronic conditions such as lung cancer to behaviours like smoking had a profound impact on the way in which public health authorities saw the public. A whole host of individual behaviours, including diet, exercise and alcohol consumption were shown to result in sickness and death. What Morris termed 'ways of living' shaped not only individual health and well-being, but health on a collective level too, as these were prevalent throughout the population (Morris 1957). To address these issues, public health authorities had to appeal to individuals. As Porter 
remarks, 'The key to the social management of chronic illnesses - such as lung cancer - was individual prevention raising health consciousness and promoting self-health care' (Porter 2011, 207). By the twenty-first century, she asserts, there is still some emphasis on the importance of social structure, social conditions and the environment on health, but health is now seen primarily as an individual responsibility (Porter 2011, 2002). This could, and indeed has, led some to argue that there is now no such thing as 'public' health, or at least that it no longer means what it did in relation to collective well-being (Le Fanu 1999; Fitzpatrick 2002). But, as this chapter has made clear, there have been and continue to be multiple ways of viewing the public and its health.

\section{CONCLUSION}

The multiplicity of 'the public' and 'public health' is one constant in a shifting story across time and place. By thinking about 'the public' as people, as a space for action, and as a set of values, we have shown that this dynamic concept can be put to a variety of uses. Additional complexities occur when we look at 'public health' and the elements that have defined it as more than just a description of death and disease at a population level. 'Public health' is shaped by the challenges it faced or faces, the systems employed to deal with these, and also a specific kind of outlook. Moreover, all these elements interact in different ways and at different times. There is no simple or single answer to the questions we posed at the outset of this chapter. Such complexity, should not, however, defy exploration or even explanation. Despite elegies for 'the public' and for 'public health' neither of these have gone away. Rather, they have been remade. In the rest of the book we explore how and why.

\section{BIBLIOGRAPHY}

Apple, Rima D. 1995. 'Constructing Mothers: Scientific Motherhood in the Nineteenth and Twentieth Centuries.' Social History of Medicine 8 (2): 161-78. Armstrong, David. 1983. Political Anatomy of the Body: Medical Knowledge in Britain in the Twentieth Century. Cambridge: Cambridge University Press. - 1995. 'The Rise of Surveillance Medicine.' Sociology of Health \& Illness 17 (3): 393-404. 
36 (1): 15-27. 'Chronic Illness: A Revisionist Account.' Sociology of Health o Illness

Baggott, Rob, Judith Allsop, and Kathryn Jones. 2005. Speaking for Patients and Carers: Health Consumer Groups and the Policy Process. Basingstoke: Palgrave Macmillan.

Baldwin, Peter. 2005. Contagion and the State in Europe, 1830-1930. Cambridge: Cambridge University Press.

Berridge, Virginia. 2016. Public Health: A Very Short Introduction. Oxford: Oxford University Press.

Bevir, Mark, and Frank Trentmann. 2007. Governance, Consumers and Citizens: Agency and Resistance in Contemporary Politics. Basingstoke: Palgrave Macmillan.

Blythe, Max. 1987. A History of the Central Council for Health Education, 1927-1968. DPhil, University of Oxford, Green College.

Brunton, Deborah. 2002. 'Policy, Powers and Practice: The Public Response to Public Health in the Scottish City.' In Medicine, Health and the Public Sphere in Britain: 1600-2000, edited by Steve Sturdy, 171-88. London: Routledge.

Calhoun, Craig J. 1992. 'Introduction: Habermas and the Public Sphere.' In Habermas and the Public Sphere, 1-48. Cambridge, MA: MIT Press.

Cantor, David. 2002. 'Representing "the Public": Medicine, Charity and the Public Sphere in Twentieth Century Britain.' In Medicine, Health and the Public Sphere in Britain: 1600-2000, edited by Steve Sturdy, 145-68. London: Routledge.

Coggon, John. 2011. What Makes Health Public? A Critical Evaluation of Moral, Legal and Political Claims in Public Health. Cambridge: Cambridge University Press.

Crook, Tom. 2007. 'Sanitary Inspection and the Public Sphere in Late Victorian and Edwardian Britain: A Case Study in Liberal Governance.' Social History 32 (4): 369-93.

- 2016. Governing Systems: Modernity and the Making of Public Health in England, 1830-1910. Oakland, CA: University of California Press.

Crook, Tom, and Glen O'Hara. 2011. 'The "Torrent of Numbers": Statistics and the Public Sphere in Britain, c. 1800-2000.' In Statistics and the Public Sphere: Numbers and the People in Modern Britain, 1-32. Abingdon, Oxon, and New York: Routledge.

Daunton, M. J. 1990. 'Housing.' In The Cambridge Social History of Britain, 1750-1950, edited by F. M. L. Thompson, 195-250. Cambridge: Cambridge University Press.

Diack, Lesley, and David F. Smith. 2002. 'Professional Strategies of Medical Officers of Health in the Post-war Period-1: "Innovative Traditionalism": The Case of Dr. Ian MacQueen, MOH for Aberdeen 1952-1974, a "Bull-Dog" with the "Hide of a Rhinoceros".' Journal of Public Health Medicine 24 (2): 123-29. 
Doll, Richard, and A. Bradford Hill. 1950. 'Smoking and Carcinoma of the Lung.' British Medical Journal 2 (4682): 739-48.

Durbach, Nadja. 2000. “"They Might as Well Brand Us”: Working-Class Resistance to Compulsory Vaccination in Victorian England.' Social History of Medicine 13 (1): 45-62.

- 2005. Bodily Matters: The Anti-vaccination Movement in England, 1853-1907. Durham, NC: Duke University Press.

Fitzpatrick, Michael. 2002. The Tyranny of Health: Doctors and the Regulation of Lifestyle. London: Routledge.

Foucault, M. 2007. Security, Territory, Population. Edited by Arnold I. Davidson and Translated by Graham Burchell. 2009 ed. Basingstoke: Palgrave Macmillan.

Fraser, Nancy. 1990. 'Rethinking the Public Sphere: A Contribution to the Critique of Actually Existing Democracy.' Social Text (25/26): 56-80.

Gorsky, Martin. 2007. 'Local Leadership in Public Health: The Role of the Medical Officer of Health in Britain, 1872-1974.' Journal of Epidemiology and Community Health 61 (6): 468-72.

- 2008. 'Public Health in Interwar England and Wales: Did It Fail?' Dynamis (Granada, Spain) 28: 175-98.

Gorsky, Martin, Karen Lock, and Sue Hogarth. 2014. 'Public Health and English Local Government: Historical Perspectives on the Impact of "Returning Home".' Journal of Public Health 36: 1-6.

Grant, Matthew. 2016. 'Historicizing Citizenship in Post-war Britain.' The Historical Journal 59 (4): 1187-1206.

Habermas, Jurgen. 1989. The Structural Transformation of the Public Sphere: An Inquiry into a Category of Bourgeois Society. Cambridge, MA: MIT Press.

Hacking, Ian. 2006. 'Making Up People.' London Review of Books 28: 23-26, 17 August.

Hamlin, Christopher. 2010. Public Health and Social Justice in the Age of Chadwick: Britain, 1800-1854. 1st Reissue ed. Cambridge: Cambridge University Press.

- 2011. 'Public Health.' In The Oxford Handbook of the History of Medicine, edited by Mark Jackson, 411-28. Oxford: Oxford University Press.

Hanley, James G. 2002. 'The Public's Reaction to Public Health: Petitions Submitted to Parliament, 1847-1848.' Social History of Medicine 15 (3): 393-411.

Hardy, Anne. 2013. 'The Public in Public Health.' In Beyond Habermas: Democracy, Knowledge and the Public Sphere, edited by Christian J. Emden and David Midgley, 87-98. New York and Oxford: Berghahn Books.

Harris, Jose. 2003. 'Tradition and Transformation: Society and Civil Society in Britain, 1945-2001.' In The British Isles Since 1945, edited by Kathleen Burk, 91-125. Oxford: Oxford University Press.

Heater, Derek. 2004. A Brief History of Citizenship. New York: New York University Press. 

. 2006. Citizenship in Britain: A History. Edinburgh: Edinburgh University
Press.

Hilton, Matthew. 2003. Consumerism in 20th Century Britain. Cambridge: Cambridge University Press.

Hogg, Christine. 2009. Citizens, Consumers and the NHS: Capturing Voices. Basingstoke: Palgrave Macmillan.

Holland, Patricia. 2013. Broadcasting and the NHS in the Thatcherite 1980s: The Challenge to Public Service. Basingstoke: Palgrave.

Krieger, Nancy. 2012. "Who and What Is a "Population"? Historical Debates, Current Controversies, and Implications for Understanding "Population Health" and Rectifying Health Inequities.' Milbank Quarterly 90 (4): 634-81.

- 2014. Epidemiology and the People's Health: Theory and Context. Oxford and New York: Oxford University Press.

Le Fanu, James. 1999. The Rise and Fall of Modern Medicine. London: Little, Brown.

Le Grand, Julian. 2003. Motivation, Agency and Public Policy: Of Knights and Knaves, Pawns and Queens. Oxford: Oxford University Press.

- 2007. The Other Invisible Hand: Delivering Public Services Through Choice and Competition. Princeton, NJ: Princeton University Press.

Lewis, Jane. 1991. 'The Public's Health: Philosophy and Practice in Britain in the Twentieth Century.' In A History of Education in Public Health: Health That Mocks the Doctors' Rules, edited by Elizabeth Fee and R. M. Acheson, 195-229. Oxford and New York: Oxford University Press.

Lewis, Jane E. 1986. What Price Community Medicine? The Philosophy, Practice and Politics of Public Health Since 1919. Brighton: Wheatsheaf Books.

Lupton, Deborah. 2014. 'The Pedagogy of Disgust: The Ethical, Moral and Political Implications of Using Disgust in Public Health Campaigns.' Critical Public Health 25: 4-14.

Marks, Lara V. 1996. Metropolitan Maternity: Maternal and Infant Welfare Services in Early Twentieth Century London. Amsterdam and Atlanta: Brill and Rodopi.

Marquand, David. 2004. Decline of the Public: The Hollowing Out of Citizenship. Cambridge: Polity Press.

Marshall, T. H. 1992. 'Citizenship and Social Class.' In Citizenship and Social Class. London: Pluto Press.

Mathews, David. 1984. 'The Public in Practice and Theory.' Public Administration Review 44: 120-25.

McKeown, Thomas. 1979. The Role of Medicine. Oxford: Blackwell.

Mold, Alex. 2015. Making the Patient-Consumer: Patient Organisations and Health Consumerism in Britain. Manchester: Manchester University Press.

- 2018. 'Exhibiting Good Health: Public Health Exhibitions in London, 1948-71.' Medical History 62 (1): 1-26.

Morris, J. N. 1957. Uses of Epidemiology. Edinburgh and London: E\&S Livingstone. 
Nathanson, Constance A. 2007. Disease Prevention as Social Change: The State, Society, and Public Health in the United States, France, Great Britain, and Canada. New York: Russell Sage Foundation.

Newman, Janet, and John Clarke. 2009. Publics, Politics and Power: Remaking the Public in Public Services. London: Sage.

Niemi, Marjaana. 2016. Public Health and Municipal Policy Making: Britain and Sweden, 1900-1940. Abingdon: Routledge.

Omran, Abdel R. 2005. 'The Epidemiologic Transition: A Theory of the Epidemiology of Population Change.' The Milbank Quarterly 83 (4): 731-57.

Oosterhuis, Harry, and Frank Huisman. 2014. 'The Politics of Health and Citizenship: Historical and Contemporary Perspectives.' In Health and Citizenship: Political Cultures of Health in Modern Europe, 1-44. London: Pickering and Chatto.

Oppenheimer, Gerald M. 2006. 'Profiling Risk: The Emergence of Coronary Heart Disease Epidemiology in the United States (1947-70).' International Journal of Epidemiology 35 (3): 720-30.

Petersen, Alan, and Deborah Lupton. 1996. The New Public Health: Health and Self in the Age of Risk. London: Sage.

Pollock, Allyson M. 2005. NHS Plc: The Privatisation of Our Health Care. New Updated ed. London: Verso Books.

Porter, Dorothy. 1999. Health, Civilization and the State: A History of Public Health from Ancient to Modern Times. London: Routledge.

. 2002. 'From Social Structure to Social Behaviour in Britain After the Second World War.' Contemporary British History 16 (3): 58-80.

-2011. Health Citizenship: Essays in Social Medicine and Biomedical Politics. Berkeley and Los Angeles, CA: University of California Press.

Rose, Nikolas. 1999. Governing the Soul: Shaping of the Private Self. London: Free Association Books.

- 2006. The Politics of Life Itself: Biomedicine, Power, and Subjectivity in the Twenty-First Century. Princeton: Princeton University Press.

- 2010. Inventing Our Selves: Psychology, Power, and Personhood. Rev. ed. Cambridge: Cambridge University Press.

Rosen, Andrew. 2003. The Transformation of British Life, 1950-2000: A Social History. Manchester: Manchester University Press.

Rosen, George. 1993. A History of Public Health. Expanded ed. Baltimore: Johns Hopkins University Press.

Rothstein, William G. 2003. Public Health and the Risk Factor: A History of an Uneven Medical Revolution. Rochester, NY: University of Rochester Press.

Royal Society of Public Health and Faculty of Public Health. 2016. Taking a New Line on Drugs. London: Royal Society of Public Health. 
Savage, Mike. 2008. 'Affluence and Social Change in the Making of Technocratic Middle-Class Identities: Britain, 1939-55.' Contemporary British History 22 (4): 457-76.

. 2015. Social Class in the 21st Century. London: Penguin Random House. Sennett, Richard. 1977. The Fall of Public Man. Cambridge: Cambridge University Press.

Stewart, Ellen. 2016. Publics and Their Health Systems-Rethinking Participation. Basingstoke: Palgrave Macmillan.

Sturdy, Steve. 2002. 'Introduction: Medicine, Health and the Public Sphere.' In Medicine, Health and the Public Sphere in Britain: 1600-2000, edited by Steve Sturdy, 1-24. London: Routledge.

Szreter, Simon. 2002. 'Rethinking McKeown: The Relationship Between Public Health and Social Change.' American Journal of Public Health 92 (5): 722-25.

- 2003. 'The Population Health Approach in Historical Perspective.' American Journal of Public Health 93 (3): 421-31.

Toon, Elizabeth. 2007. “"Cancer as the General Population Knows It”: Knowledge, Fear, and Lay Education in 1950s Britain.' Bulletin of the History of Medicine 81 (1): 116-38.

Verweij, M. F., and Angus Dawson. 2007. 'The Meaning of "Public" in "Public Health".' In Ethics, Prevention, and Public Health, edited by M. F. Verweij and Angus Dawson, 13-29. Oxford: Clarendon Press.

Warner, Michael. 2002a. 'Publics and Counterpublics.' Public Culture 14 (1): 49-90.

-2002b. Publics and Counterpublics. New York and Cambridge, MA: Zone Books and Distributed by MIT Press.

Webster, Charles. 1988. The Health Services Since the War, Volume 1: Problems of Health Care, the National Health Service Before 1957. London: HMSO.

Weisz, George. 2014. Chronic Disease in the Twentieth Century: A History. Baltimore: Johns Hopkins University Press.

Weisz, George, and Jesse Olszynko-Gryn. 2010. 'The Theory of Epidemiologic Transition: The Origins of a Citation Classic.' Journal of the History of Medicine and Allied Sciences 65 (3): 287-326.

Welshman, John. 1997a. “"Bringing Beauty and Brightness to the Back Streets”: Health Education and Public Health in England and Wales, 1890-1940.' Health Education Journal 56 (2): 199-209.

- 1997b. 'The Medical Officer of Health in England and Wales, 1900-1974: Watchdog or Lapdog?' Journal of Public Health Medicine 19 (4): 443-50.

- 2001. Municipal Medicine: Public Health in Twentieth-Century Britain. lst ed. Oxford and New York: Verlag Peter Lang.

Winslow, C.-E. A. 1920. 'The Untilled Fields of Public Health.' Science 51 (1306): 23-33. 
Open Access This chapter is licensed under the terms of the Creative Commons Attribution 4.0 International License (http://creativecommons.org/licenses/by/ 4.0/http://creativecommons.org/licenses/by/4.0/), which permits use, sharing, adaptation, distribution and reproduction in any medium or format, as long as you give appropriate credit to the original author(s) and the source, provide a link to the Creative Commons license and indicate if changes were made.

The images or other third party material in this chapter are included in the chapter's Creative Commons license, unless indicated otherwise in a credit line to the material. If material is not included in the chapter's Creative Commons license and your intended use is not permitted by statutory regulation or exceeds the permitted use, you will need to obtain permission directly from the copyright holder.

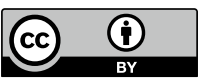

